\title{
The impact of wildfire on stream fishes in an Atlantic- Mediterranean climate: evidence from an 18-year chronosequence
}

\author{
K.A. Monaghan ${ }^{1, \star}$, A.L. Machado ${ }^{1}$, F.J. Wrona ${ }^{1,2}$ and A.M.V.M. Soares ${ }^{1,3}$ \\ 1 CESAM and Departmento de Biologia, Universidade de Aveiro, Campus Universitario de Santiago, 3810-193 Aveiro, Portugal \\ 2 Water and Climate Impacts Research Centre (W-CIRC), Environment Canada, Department of Geography, University of Victoria, \\ Victoria, BC, Canada \\ 3 Programa de Pós-Graduação em Produção Vegetal, Universidade Federal do Tocantins, Campus de Gurupi. Rua Badejós, Zona Rural, \\ Cx. Postal 66, 77402-970 Gurupi-TO, Brasil
}

Received December 4, 2015 - Revised April 29, 2016 - Accepted May 11, 2016

\begin{abstract}
The predicted increase in wildfires associated with climate change poses a risk to freshwater biodiversity that may be exacerbated by river regulation. We studied the effects of wildfire and river management on the fish assemblages of Atlantic-Mediterranean streams in northern Portugal. Employing a chronosquence survey covering an 18-year gradient of impact-recovery from major fire events (ca. 100\% catchment burnt), we assessed the ecological response with respect to time since wildfire, interpreting fish assemblages in the context of species traits and characteristics of the river habitat. Non-burnt sites $(N=18$; surveyed 4 years previously) were compared to burnt sites $(N=14)$, two of which were part of the non-burnt set, thus providing a Before-After Impact comparison (BAI; $N=2$ ). Across burnt sites richness and abundance were not related to time since wildfire. BAI revealed a contrast in the response of different species that corresponded to descriptive evidence from the chronosequence of burnt sites. As resource specialists, Salmo trutta were negatively impacted by wildfire; Iberian endemic cyprinids, characterized by generalist traits, demonstrated resistance. Habitat structure was a key determinant of wildfire-impact, increasing with channel slope and the degree of channelization. The low abundance of migratory taxa ( $S$. trutta and Anguilla anguilla) at burnt sites suggested the importance of fish mobility to post-fire recovery. These data demonstrate that trait profiles and habitat descriptions provide pragmatic information for the management of rivers in fire-susceptible regions and suggest that the rehabilitation of these upland stream habitats might enhance ecological resistance and resilience to catchment wildfire.
\end{abstract}

Key-words: wildfire / fishes / species traits / Mediterranean streams / river habitat / conservation management

Résumé - L'impact des incendies sur les poissons des cours d'eau en climat atlantique-méditerranéen : étude d'une chronoséquence de $\mathbf{1 8}$ ans. L'augmentation prévue des incendies associés au changement climatique pose un risque pour la biodiversité d'eau douce, qui peut être aggravé par la régulation de la rivière. Nous avons étudié les effets des feux et de la gestion de la rivière sur les peuplements de poissons de cours d'eau dans le nord du Portugal. Étudiant la chronoséquence d'un suivi couvrant une durée de 18 ans d'impact-récupération d'incendies majeurs (environ $100 \%$ du bassin versant brûlé), nous avons évalué la réponse écologique temporelle à un incendie, en analysant les assemblages de poissons dans le contexte des traits d'espèces et des caractéristiques de l'habitat de la rivière. Les sites non brûlés $(N=18$; suivis 4 ans auparavant) ont été comparés à des sites brûlés $(N=14)$, dont deux faisaient partie de l'ensemble non brûlé, offrant ainsi une comparaison avant-après l'impact (BAI; $N=2$ ). Parmi les sites brûlés la richesse et l'abondance ne sont pas liées au temps depuis l'incendie. BAI a révélé un contraste dans la réponse des différentes espèces qui découlait des données descriptives de chronoséquence des sites brûlés. En tant que spécialiste alimentaire, Salmo trutta a été négativement impactée par les incendies ; les cyprinidés endémiques ibériques, caractérisés par des traits généralistes, ont démontré une résistance. La structure de l'habitat a été un facteur déterminant de l'impact des incendies, qui augmente avec la pente de la rivière et le degré de canalisation. La faible abondance de taxons migrateurs (S. trutta et Anguilla anguilla) sur les sites brûlés, a suggéré l'importance de la mobilité des poissons à la récupération

^ Corresponding author: kamonaghan@ua.pt 
post-feu. Ces données démontrent que les profils de traits de vie et les descriptions de l'habitat fournissent des informations pragmatiques pour la gestion des cours d'eau dans les régions sensibles au feu et suggèrent que la remise en état de ces habitats de cours d'eau de montagne pourrait améliorer la résistance et la résilience écologique aux incendies dans un bassin versant.

Mots-clés : feux de forêt / poissons / traits d'espèces / cours d'eau méditerranéens / habitat en rivière / gestion de la conservation

\section{Introduction}

Wildfire $^{1}$ represents a major determinant of the structure and function of terrestrial ecosystems worldwide (Bond and Keeley, 2005; Bowman et al., 2009). In fire-prone regions it acts over evolutionary time-scales, selecting species traits for survival and post-fire proliferation (Pausas and Keeley, 2009), over ecological time-scales it represents a landscape process that maintains communities of fire-adapted species (Pausas et al., 2004b). For lotic ecosystems that drain fireimpacted catchments, fire represents a ramifying disturbance with ecological effects that can extend for years after the fire event (Minshall et al., 1997; Gresswell, 1999; Minshall, 2003). Whilst a growing number of studies have documented the adaptive resilience of terrestrial flora and fauna in fire-prone regions of North America (Johnstone et al., 2011), and Europe (Arnan et al., 2006; Kiss and Magnin, 2006; Pausas et al., 2008), studies on the effects of fire on the hydrology, geochemistry and ecological structure and function of lotic ecosystems is comparatively recent (Dunham et al., 2003; Minshall, 2003). This knowledge gap is particularly acute for river ecosystems in Mediterranean climates where aquatic life has evolved under comparatively frequent fire disturbance (Verkaik et al., 2013).

Human activities have altered the regime of wildfires beyond their natural historic range (Syphard et al., 2007; Batllori et al., 2013), often driven by changes in landuse (Pausas et al., 2008). In Mediterranean Europe, the abandonment of farmland and the plantation of commercial forests (for the wood and paper industry) have contributed to the increased frequency and spatial extent of wildfire (Moreira et al., 2001; Pausas, 2004; Pausas et al., 2004a). At the same time, human intervention in Mediterranean rivers has transformed the interaction between aquatic and terrestrial environments. Dam construction has interrupted the longitudinal connectivity of river ecosystems and channelization has reduced habitat heterogeneity and increased the isolation of water courses from the terrestrial environment, disrupting the dynamics of aquaticriparian interactions (Brookes, 1988; Santos et al., 2006). In the face of catchment wildfire these altered river habitats may present a synergistic interaction with fire related disturbance that could both exacerbate disturbance processes and impede ecological recovery. As predictions of climate change include an increasing risk of wildfire and a reduction in precipitation across Mediterranean regions, coupled with a subsequent rise in the exploitations of their freshwater resources (IPCC WGII, 2014), a contextual understanding of the impact of these

1 Wildfire is defined here as an uncontrolled fire of human or natural origin. compounded disturbance processes represents crucial knowledge for the conservation management of Mediterranean rivers (Verkaik et al., 2013).

While the potential importance of compounded fire-habitat impacts has recently been addressed for lotic macroinvertebrates (Mellon et al., 2008), information on stream fishes remains scarce (Verkaik et al., 2013). As fish are permanently restricted to the stream channel, their potential for ecological resistance and resilience to disturbance differs to that of invertebrates. This distinction is particularly acute in the case of wildfire that, as a predominantly summer-time phenomenon, typically coincides with the adult phase of aquatic insects when their comparatively high mobility facilitates their resilience by avoidance of benthic habitats and subsequent aerial recolonization, supplemented from neighbouring populations (Minshall, 2003; Alvarez-Cabria et al. 2011). Fish, in contrast, may be particularly vulnerable: surviving in Mediterranean rivers at their natural stress maximum associated with seasonal low flows, increased temperatures, and low levels of dissolved oxygen (Magalhaes et al., 2007; Pires et al., 2010). Coinciding with these seasonal environmental bottlenecks and their limited potential for impact avoidance, the ramifying disturbance of wildfire acting in modified river habitats may be particularly damaging for riverine fishes. Yet with comparatively long lifecycles and potentially high in-stream mobility in general, this spatio-temporal knowledge gap has proved difficult to address; it requires a survey design based at the catchment scale and covering extended time periods (Verkaik et al., 2013).

Over the last two decades wildfire in mainland Portugal has consumed an average of $100000 \mathrm{Ha}$ of land each year (Amorim et al., 2011). Spatially extensive fires predominantly occur in the mountainous northern half of the country where human modification of upland stream habitat is widespread (Chaves et al., 2005; Monaghan et al., 2008). The continental territory hosts a diverse assemblage of fish: 51 species are registered from freshwaters, 18 are Iberian endemics, five are unique to Portugal and 15 are introduced (Ribeiro et al., 2007). Although characterized by low taxa richness, upland tributary streams are largely free from invasive species and their associated impact on native fauna (Magalhaes et al., 2002; Clavero and Garcia-Berthou, 2006). Upland streams therefore provide important refugia for native species and represent river habitats of high conservation value (Ribeiro et al., 2000; Filipe et al., 2004; Ribeiro et al., 2009). As these upland landscapes are particularly susceptible to large-scale wildfire (Amorim et al., 2011) and because the ecological impact of wildfire is inversely proportional to stream size (the smaller the stream, the greater the impact; Minshall et al., 2003), these remote upland ecosystems may be particularly vulnerable to fire-related disturbance. 
This study addresses one of the fundamental challenges of fire-ecology highlighted in the recent synthesis of Verkaik et al. (2013) by assessing the effects of wildfire on fish communities in upland Portuguese streams. The increase in both the scale and frequencies of catchment wildfire over recent decades have provided a fortuitous study context whereby wildfire disturbance has been replicated along a gradient of time that consequently represents a chronosequence, so that space can be substituted for time, with respective catchments providing a discrete spatio-temporal snap-shot of the disturbance-recovery process. Based on an 18-year chronosequence of streams impacted by catchment-wide wildfire (ca. $100 \%$ of the upstream drainage basin burned) we investigated the role of the river habitat as a mediator of disturbance and recovery and considered how species traits influence the ecological response. We tested the hypotheses that: (i) ecological recovery (species richness and abundance) is related to time since a fire event; (ii) community response is determined by species traits: vulnerability increasing with resource specialism and recovery related to mobility behaviour; (iii) the ecological impact of fire is exacerbated by human modification of river habitats.

\section{Methods}

\subsection{Site selection}

Details of wildfires since January 1990 were supplied by Conservação da Natureza e das Florestas (ICNF). Burned areas were mapped using ArcGis (9.2). Candidate sites were limited to river catchments subject to a single wildfire event where ca. $100 \%$ of the upstream catchment area was burned; in some cases small areas $(<8 \%)$, distant from stream systems (i.e. mountain ridges), did not burn. Further discrimination was based on otherwise least-impacted criteria: excluding streams close to urban or industrial development and catchments with $>15 \%$ agricultural landuse. Collectively, these criteria limited candidate sites to small upland streams in central and northern Portugal.

Data were used to establish a chronosequence of sites, classified by years since wildfire occurrence (substituting space for time). Site selection was ultimately based on inspection to confirm that the stream represented an aquatic system sufficiently large to support fish. As we expected the years immediately following the fire event to be the most dynamic in terms of recovery, and were otherwise limited by the stochasticity of fire events (years, area, location, etc.), our chronosequence was composed of 14 sites (selected from the qualifying candidate sites) that burned: 1, 2, 2, 2, 3, 3, 4, 5, 7, 10, 10, 15, 17 and 18 years previous to ecological surveys (where fires spanned years 1990-2008). The catchment area of each stream was determined from 1:50000 military maps, defined by a polygon encompassing all first order rivers upstream of the study site. The proportion $(\%)$ of catchment area burned was calculated by superimposing burned-shapes over catchment areas (described as GIS layers). Additional map derived variables included channel slope (measured over $1 \mathrm{~km}$ ), Stream Link
Magnitude (SLM), altitude, and the presence of dams (within $3 \mathrm{~km}$ downstream of the survey sites).

Data from a previous survey (conducted in 2004) was used to provide information on fish communities in streams not impacted by wildfire (Monaghan et al., 2008). The fire history of these 31 sites was analysed by the same GIS mapping technique, superimposing the available historical fire data (19902004) over respective catchment areas. Sites with $>5 \%$ of their upstream catchment burned during any single year were excluded (this included the exclusion of two streams without fish). Eighteen sites were retained (Table 1). Non-burnt sites $(N=18)$ and burnt sites $(N=14)$ sites were comparable in terms of stream size (SLM) and altitude, while slope was generally higher at burnt compared to non-burnt sites $\left(F_{1,30}=10.46 ; P<0.05\right)$. Two of the non-burnt sites, surveyed in 2004, had subsequently experienced catchment-wide wildfire (burning in 2005 and 2006 respectively), thus providing two examples of a Before-After Impact (BAI) survey.

\subsection{Ecological surveys}

All surveys were conducted during the late summer, lowwater period (mid-August to mid-September). Non-burnt sites were surveyed in 2004; fire-impacted sites were surveyed in 2008, except Feridouro, which was surveyed in 2009 (inaccessible in 2008). Fish sampling was achieved by multiple pass (3×) electrofishing using 300w AC backpack equipment over a delineated reach, not less than $50 \mathrm{~m}$. Fish were processed on the bank-side and distinguished according to the taxonomic classification of Kottelat and Freyhof (2007) and Leunda et al. (2009). The physical structure of lotic habitats was characterised by a habitat survey based on the River Habitat Survey and HABSCORE (Wyatt et al., 1995; Environment Agency, 2003) modified for use in Portuguese streams. The survey involved recording details of the channel, banks and riparian zone (substrate size, flow, cover, shade, etc.) in terms of discrete qualitative classes from observations made across transects conducted every $20 \mathrm{~m}$ over a longitudinal reach of $200 \mathrm{~m}$ (see Environment Agency 2003; Monaghan and Soares, 2010). Key physico-chemical variables were measured on site using portable meters: temperature, $\mathrm{pH}$, conductivity, dissolved oxygen. Water samples from fire-impacted sites were subject to chemical analysis for nutrients, key ions and potential toxins $\left(\mathrm{NH}_{3}, \mathrm{NO}_{3}, \mathrm{NO}_{2}, \mathrm{HCN}, \mathrm{PO}_{4}, \mathrm{SO}_{4}, \mathrm{Mg}, \mathrm{K}, \mathrm{Ca}, \mathrm{Fe}, \mathrm{Na}, \mathrm{Zn}, \mathrm{N}\right.$, $\mathrm{Si}, \mathrm{Cl}, \mathrm{Al}, \mathrm{Cd}, \mathrm{Pb}, \mathrm{Cu})$.

Field and laboratory work did not contravene national and international law on Human and Animal Rights.

\subsection{Data analyses}

Principle Component Analysis (PCA) was used to simplify the multivariate data from river habitat surveys from burnt sites, generating linear gradients in habitat characteristics represented by the resultant ordination axes. Prior to creating the data matrix, nominal categories of size or complexity (e.g. substrate size, riparian vegetation structure) were digitalized as ordinal scores (minimum range 1-5). Categories 
Table 1. Summary of study sites; N/A signifies that in any single year the occurrence of fire(s) upstream of the study site covered $<5 \%$ of the corresponding catchment area for the period 1990-2004, inclusive.

\begin{tabular}{|l|c|c|c|c|c|c|}
\hline Name & Code & $\begin{array}{c}\text { Co-ordinates } \\
\text { (lat., long.) }\end{array}$ & $\begin{array}{c}\text { Years } \\
\text { since fire }\end{array}$ & $\begin{array}{c}\text { Stream Link } \\
\text { Magnitude }\end{array}$ & $\begin{array}{c}\text { Altitude } \\
\text { (m a.s.1.) }\end{array}$ & $\begin{array}{c}\text { Slope } \\
(1 \mathrm{~km})\end{array}$ \\
\hline Múceres & $\mathrm{Mu}$ & $4032.3,810.2$ & 18 & 21 & 410 & 90 \\
Louritela & Lot & $4038.3,818.4$ & 17 & 40 & 130 & 70 \\
Covas & $\mathrm{Cv}$ & $4159.9,840.9$ & 15 & 10 & 250 & 100 \\
Agua de Alte & $\mathrm{AdA}$ & $4048.1,751.6$ & 10 & 19 & 550 & 80 \\
Cabrum & $\mathrm{Cb}$ & $4047.5,752.9$ & 10 & 96 & 430 & 60 \\
São Miguel & $\mathrm{SMig}$ & $4012.8,810.8$ & 7 & 34 & 570 & 20 \\
Penha de Águia & $\mathrm{PdA}$ & $4059.6,729.6$ & 5 & 20 & 430 & 50 \\
Feridouro & $\mathrm{Fd}-\mathrm{B}$ & $4031.6,820.5$ & 4 & 69 & 150 & 30 \\
Rib. do Boialvo & $\mathrm{Boal}$ & $4030.1,820.6$ & 3 & 44 & 170 & 40 \\
Viadel & $\mathrm{Vd}$ & $4050.9,818.2$ & 3 & 15 & 550 & 120 \\
Bouça Donas & $\mathrm{BD}$ & $4154.3,818.8$ & 2 & 12 & 770 & 120 \\
Carrazedo & $\mathrm{Cz}-\mathrm{B}$ & $4041.2,919.6$ & 2 & 12 & 600 & 150 \\
Lameirinhos & $\mathrm{Cz2}$ & $4041.4,819.6$ & 2 & 30 & 380 & 90 \\
Tijão & $\mathrm{RdV}$ & $4120.3,757.0$ & 1 & 5 & 320 & 175 \\
Aguicheira & $\mathrm{Agch}$ & $4049.9,822.3$ & N/A & 23 & 240 & 50 \\
A.das Cabras & $\mathrm{AdC}$ & $4052.0,816.0$ & N/A & 16 & 945 & 20 \\
Arões & $\mathrm{Ar}$ & $4048.0,818.1$ & N/A & 29 & 472 & 28 \\
Carrapichana & $\mathrm{Ca}$ & $4034.4,728.0$ & N/A & 25 & 476 & 25 \\
Carrazedo & $\mathrm{Cz}-\mathrm{A}$ & $4041.2,919.6$ & N/A & 12 & 600 & 150 \\
Contige & $\mathrm{Ctg}$ & $4043.8,744.9$ & N/A & 22 & 452 & 68 \\
Cortêz & $\mathrm{Ctz}$ & $4039.2,817.5$ & N/A & 9 & 255 & 60 \\
Feridouro & Fd-A & 4031.6820 .5 & N/A & 69 & 150 & 30 \\
Lousã & Lou & 405.8814 .0 & N/A & 17 & 240 & 50 \\
Marameleira & $\mathrm{Mla}$ & $4021.1,815.5$ & N/A & 30 & 100 & 15 \\
Mosteirinho & $\mathrm{Mst}$ & 4031.8815 .1 & N/A & 27 & 300 & 40 \\
Povinha & $\mathrm{Pvh}$ & $4033.1,819.3$ & N/A & 6 & 100 & 100 \\
Póvoa do Gago & $\mathrm{PdG}$ & $4027.6,822.0$ & N/A & 31 & 120 & 30 \\
Póvoa do Sebo & $\mathrm{PdS}$ & 4028.2812 .7 & N/A & 22 & 225 & 45 \\
Ribeira de Fráguas & $\mathrm{RdF}$ & 4045.2826 .4 & N/A & 57 & 160 & 35 \\
Sardoal & $\mathrm{Sdl}$ & 4027.5815 .6 & N/A & 31 & 178 & 22 \\
Sul & $\mathrm{Sul}$ & 4051.081 .9 & N/A & 34 & 249 & 46 \\
Tourigo & $\mathrm{Trg}$ & 4028.2810 .9 & N/A & 39 & 170 & 35 \\
\hline
\end{tabular}

for Bank Profile (i.e. vertical, vertical+toe, steep, gentle, etc.) were expressed as an ordinal scale of increasing steepness (16). Channel vegetation was converted to a cumulative score of diversity and architectural complexity (0-21). All other variables included in the PCA represented continuous measurements. Characteristics of the channel, banks and riparian habitats were analysed separately with the resultant Principal Components (PCs) used to describe the major gradients in channel (Chan 1), bank (Bnks 1) and riparian (Rip 1) characteristics across sites. Site scores were based on the centroid of transect data for each site. Potential environmental drivers of reach-scale habitat characteristics were, in turn, analysed with respect to habitat PCs by Pearson's product-moment correlation: watershed slope, altitude, Stream Link Magnitude and the extent of bank management (recorded as the frequency of occurrence of bank modifications in transect records).

Chemical descriptors at fire-impacted sites were analysed by multiple regression where years since fire event and stream size (Stream Link Magnitude) represented predictor variables. Where appropriate, variables of water quality were square-root or log transformed so that data across sites approximated to a normal distribution. For variables with sufficient data (i.e. excluding variables that tended to be below minimum detection levels at $>5$ sites), a minimum adequate model was developed by the manual, step-wise removal of non-significant terms $(P>0.05)$.

Fish species that occurred at one site only were not included in statistical analysis (resulting in the exclusion of two species, present at a single non-burnt site). Differences in ecological and environmental data between burnt and non-burnt sites were compared by one-way ANOVA.

To address hypothesis (i) the diversity and abundance fishes at burnt sites was assessed in relation to time since wildfire. To test hypothesis (ii) species traits were classified according to published information (FAME, 2005; Kottelat and Freyhof, 2007). Differences in the occurrence of traits at burnt and non-burnt sites were compared by creating a data matrix based on Gower distances, projected in statistical space by Principal Co-ordinate analysis (PCo; Legendre and Legendre, 2012).

Hypotheses (i) and (iii) were addressed by a constrained ordination of burnt sites. As we considered fish absence to be relevant data, we assessed the ecological importance of environmental variables at burnt sites by Partial Redundancy 
Table 2. Summary of habitat descriptors for the channel, banks and riparian vegetation based on principal component analysis (PCA), axis loadings in parentheses.

\begin{tabular}{|l|c|c|}
\hline $\begin{array}{l}\text { Chan 1 } \\
(74.0 \%)\end{array}$ & $\begin{array}{c}\text { Bnks 1 } \\
(51.5 \%)\end{array}$ & Rip 1 \\
\hline Cobbles $(+0.75)$ & Undercut banks $(+0.41)$ & Deciduous shade $(+1.00)$ \\
Pebbles $(+0.65)$ & Bank top width $(+0.25)$ & Veg. complexity $-1 \mathrm{~m}(+0.53)$ \\
Gravel $(+0.44)$ & & Veg. complexity $-5 \mathrm{~m}(+0.26)$ \\
& & Veg. complexity - face $(+0.21)$ \\
Depth $(-0.22)$ & & \\
Submerged roots $(-0.24)$ & & \\
Emergent rocks $(-0.31)$ & Bank top height $(-0.50)$ & \\
Boulder Cover $(-0.42)$ & Substrate size $(-0.80)$ & Herbaceous shade $(-0.19)$ \\
Bedrock $(-1.00)$ & Bank profile index $(-0.84)$ & \\
\hline
\end{tabular}

Analysis (pRDA) that preserves the Euclidean distance and thus incorporates zero data values. Significance tests were used to evaluate the importance of habitat characteristics by sequentially describing environmental parameters as canonical axes, while treating all other parameters as co-variables and conducting a Monte Carlo permutation test (Legendre and Legendre 2012). Hypothesis (i) was tested by setting the variable time since wildfire (years) as the canonical axis, while hypothesis (iii) was tested by assessing the respective importance of habitat features (Chan 1, Bnks 1, Rip 1) to ecological data and subsequently relating these architectural descriptors to the extent of human modification (by correlation, see above). Hypothesis (iii) was also evaluated by applying Fisher's Exact Test to count data expressing the presence/absence of fish with respect to the existence of artificial obstacles to migration: barriers vs no barriers (i.e. downstream presence of dams, stepped culverts).

\section{Results}

For the river channel, banks and riparian zone over half the total variation of their respective PCA's was explained by the primary ordination axes. Chan 1 described a transition in channel substrate size, depth, cover and habitat complexity. Bnks 1 described a transition in bank cover, substrate size and bank profile. Rip 1 described a transition in vegetation complexity and overhead shade (Table 2).

Most water quality descriptors at fire-impacted sites were below the analytical detection limits. While the concentrations of several chemical variables tended to increase with stream size, regression analysis revealed that this trend was only significant for potassium $(P=0.04)$. Two other chemical variables demonstrated complex relationships with time since wildfire events. Dissolved silica decreased with years since fire $(P=0.03)$ while positively covarying with stream size $(P=0.01)$. Conversely, aluminium increased with years since fire $(P=0.02)$ while negatively covarying with stream size $(P=0.04)$. Observed changes in water temperature, conductivity and $\mathrm{pH}$ were independent of both stream size and time since the fire event.

Overall taxa richness was low with fish assemblages dominated by five species composed of three Iberian endemics: Northern Iberian chub (Squalius carolitertii),
Ruivaco (Achondrostoma oligolepis), Caladinho (Squalius alburnoides); brown trout (Salmo trutta), and the European eel (Anguilla anguilla). Mean taxa richness was significantly higher at non-burnt sites compared to burnt sites $\left(F_{1,30}=\right.$ 32.55; $P<0.001)$. There was no clear relationship between time and taxa richness and abundance at burnt sites (Figure 1). Six of the burnt sites were fishless, including sites that had been impacted a relatively long time prior to ecological surveys $(10,15,17$ years). Several recently burned sites $(3,4,7$ years) supported fish populations that were comparable to nonburnt sites in terms of taxa richness and abundance (Figure 1).

The primary axis of trait analysis differentiated the generalist traits (+ve) of fractional spawning (i.e., repeatedly throughout the year), lentic tolerance and trophic generalism (omnivory), from the specialist traits (-ve) of autumn/winter spawning, invertivorous diet, water quality-sensitive (after FAME 2005), habitat quality-sensitive (FAME 2005) and potamodromous migration (Table 3; Figure 2). The secondary axis was distinguished by the European eel (+ve) with the behavioural traits of long distance migration and Marine (catadromous) reproduction. All recently impacted sites supporting fish (burned 3, 4, 7 years previously) were positive on the primary axis. One burnt site, impacted 10 years previously, was positioned on the negative extremity of the primary axis and represented the capture of a single individual trout.

The response of fish assemblage at the two sites constituting the BAI survey differed. In 2004 the Feridouro site supported abundant populations of Northern Iberian Chub and Ruivaco and revealed comparable fish assemblages and abundance patterns after the 2005 wildfire (Figures 3a and 3b). In contrast at the Carrazedo site, Brown Trout were present in 2004 but following wildfire in 2006, no fish were captured during the post-fire survey (Figures $3 \mathrm{c}$ and $3 \mathrm{~d}$ ).

At burnt sites pRDA distinguished a significant relationship between fish community structure and characteristics of the channel (Chan 1; $F=7.109, P<0.05$ ), bank habitat (Bnks $1 ; F=9.134, P<0.01$ ) and water quality (conductivity; $F=5.276, P<0.05$ ). These summarized PC gradients in channel habitat and bank habitat were, in turn, respectively correlated with stream slope $(-0.688 ; P<0.01)$ and the extent of bank management $(-0.602 ; P<0.05)$. Assessing obstacles to migration, Fisher's Extact Test reported no significant differences between presence/absence of fish and the presence/absence of downstream barriers. 


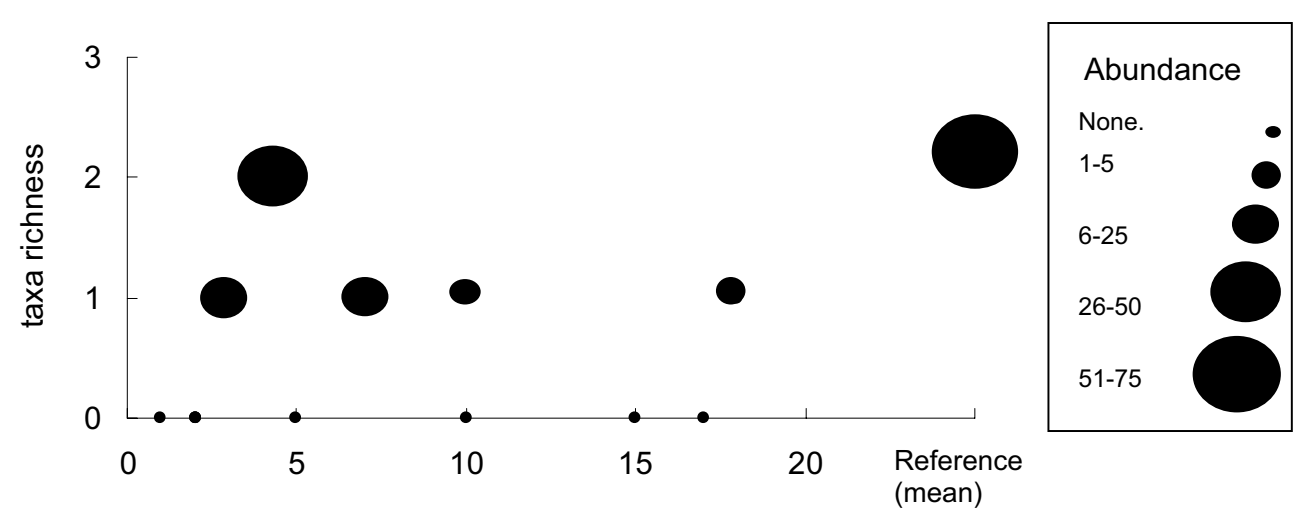

Fig. 1. Taxa richness and fish abundance in relation to time since wildfire impact. The mean value for the eighteen non-impacted, references sites are also shown.

Table 3. Summary of PCo axes score (based on Gower distances) for fish species traits (capital letters are coded abbreviations used as labels in Fig. 2). Trait descriptions are based on a priori information from the literatures (see Methods).

\begin{tabular}{|l|c|}
\hline Axis 1 (46\%) & Axis 2 (21\%) \\
\hline Fractional spawner (SPWN F; 0.256) & Migration Long (MIG L; 0.222) \\
Lentic (LEN; 0.327) & Marine spawner (SPWN M; 0.222) \\
Marine spawner (SPWN M; 0.143) & General spawner (SPWN G; 0.050) \\
Migratory long (MIG L; 0.143) & Trophic omnivore (TRP O; 0.180) \\
Trophic omnivore (TRP O; 0.130) & Trophic invertivore (TRP I; 0.042) \\
General spawner (SPWN G; 0.100) & \\
& Habitat quality (HQ; -0.004) \\
Migration Potamodromous (MIG P; -0.256) & Water quality (WQ; -0.022) \\
Trophic invertivore (TRP I; -0.256) & Lentic (LEN; -0.065) \\
Autmn spawning (SPWN A; -0.256) & Fractional spawner (SPWN F;-0.102) \\
\hline
\end{tabular}

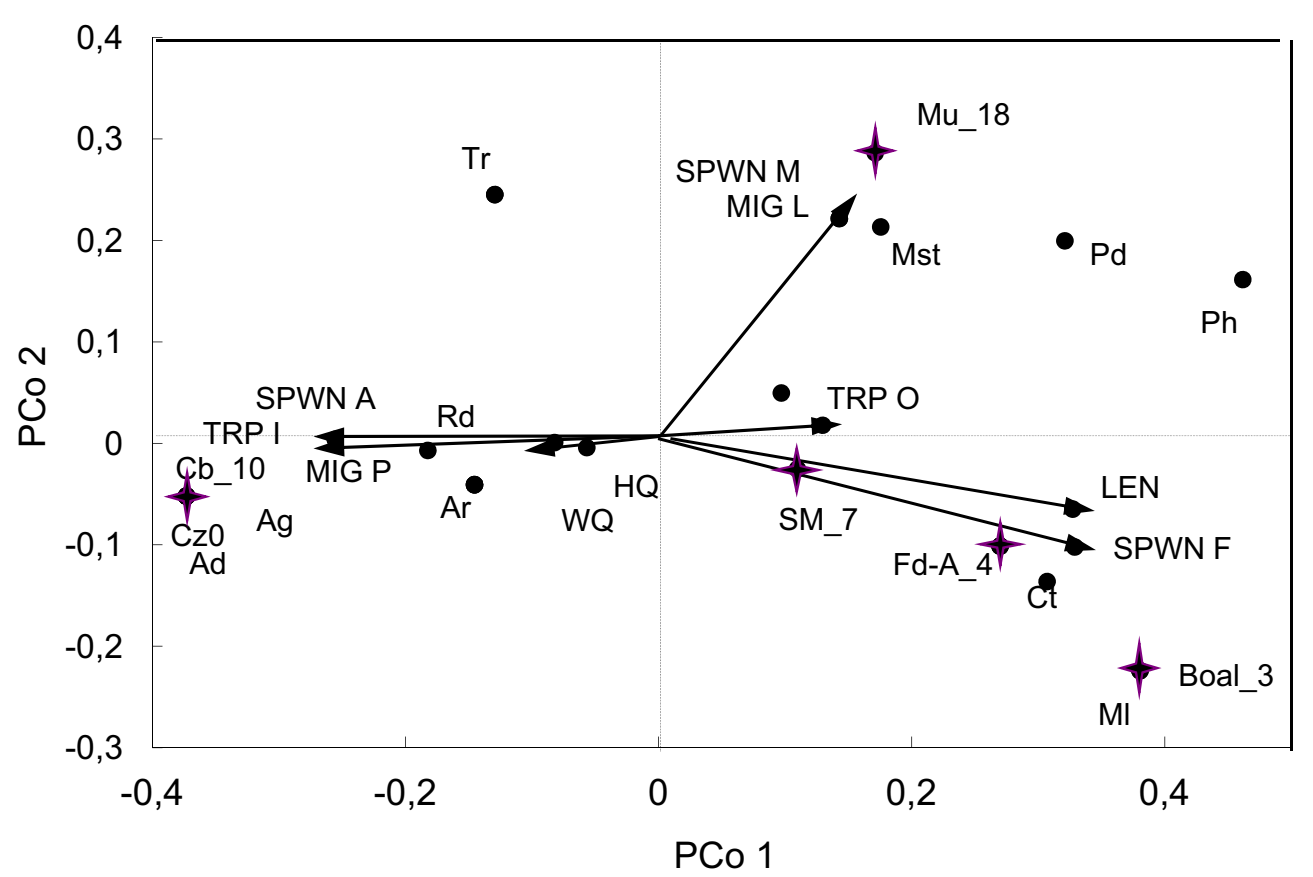

Fig. 2. Principal Co-ordinate analysis (based on Gower-distances) of species traits of fish inhabiting fire impacted (stars) and non-burnt (circles) upland streams in mainland Portugal. Fire-impacted sites are followed by a number indicating the years since fire impact. Traits are represented by arrows and coded according to Table 3 . 


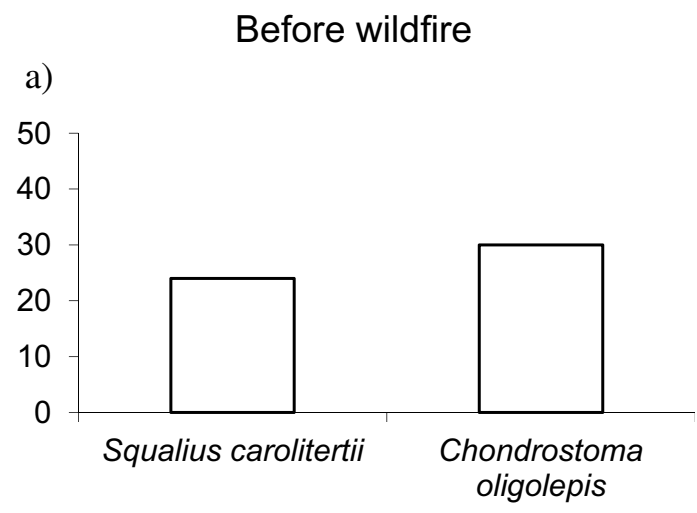

c)

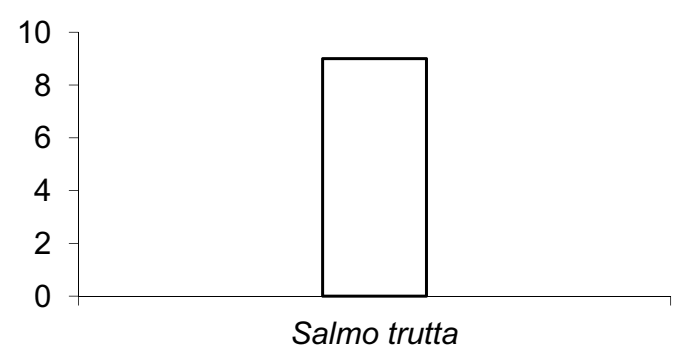

After wildfire

b)

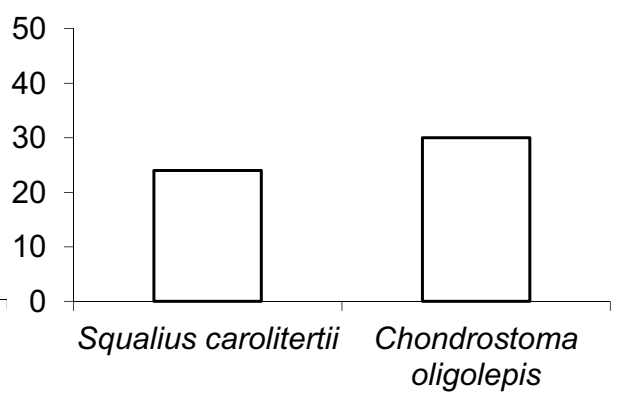

d)

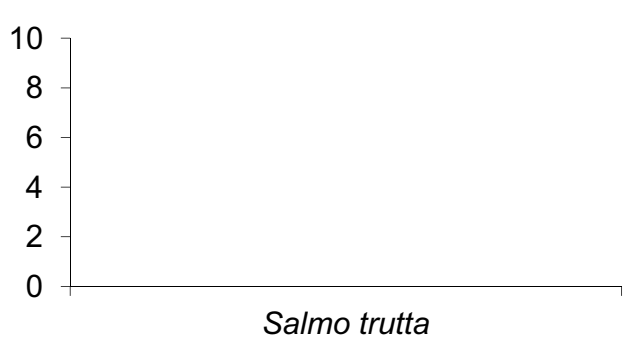

Fig. 3. Histograms of fish species abundance at sites impacted by wildfire illustrating assemblages before (a and c) and after (b and d) catchment wide wildfire impact.

\section{Discussion}

This study indicates that wildfire in upland Mediterranean stream catchments can have a negative impact on fish assemblages and that recovery may not be a simple function of time (contradicting our hypothesis (i)). While this comparatively small study limits the scope for definitive conclusions, the catchment-scale replication of sequential fire-impacts suggests that the impact/recovery of natural systems is determined by their ecological and environmental context. Results from the BAI sites and the descriptive survey indicates that the apparent difference in the resistance and resilience of fishes corresponded to the contrasting biological characteristics of species (trophic and reproductive strategies; mobility and migration); providing support for hypothesis (ii). Environmental correlates at the local and catchment scale (channel and bank habitat; slope and bank management) from burnt sites suggests the importance of catchment erosion and associated physical disturbance processes as a key driver of the ecological impact. Human modifications of river habitats (bank management, damming) can increase the destructive power of catchment erosion and impede ecological recovery however, despite tentative support for hypothesis (iii), evidence from this study was inconclusive. The ecological processes most likely to explain the direct and correlative evidence of wildfire impact in this study can be inferred by interpreting these findings in the light of previous research.

An increase in water temperatures during wildfire can cause direct mortality to fish and their invertebrate food resources (Spencer and Hauer, 1991). At the same time strong peaks in the concentration of nitrate, ammonium and phosphate may result from the diffusion of smoke gases and the leaching of ash (Spencer et al., 2003). The small, isolated rivers of this study may have been particularly susceptible to this type of pulsed-disturbance in water quality (Minshall, 2003). Ramchunder et al. (2013) reported increased levels of cations and suspended sediments associated with the chronic effects of repeated catchment burning for streams in Northern England. The indication of a potential temporal trend in Silica and Aluminium concentrations from these chronosequence streams suggest a similar response in water quality might also be important for one-off fire events (Verkaik et al., 2013).

Carbonized material and the exposure of top soils resulting from catchment wildfire can cause extreme erosion and debris slides that wash through stream systems (Minshall, 1989; Shakesby 2011). Repeated hydrologic disturbance decreases channel stability, reduces the availability and quality of fish habitat such as course woody debris and can decimate benthic invertebrate food resources (Rinne, 1996; Gresswell, 1999; Benda et al., 2003; Vaz et al. 2011; 2014). The increase in suspended sediments and associated sedimentation can cause fish and invertebrate mortalities and can entomb benthic eggs and larvae (Rieman and Clayton, 1997; Cooper et al. 2015). These disturbance processes present a biological risk that is ultimately a function of the ecological traits of the species present that, in turn, determine how respective species interact with the river environment in both space and time.

While trout were often abundant in non-burnt streams, they were never abundant in burnt streams. In contrast native Cyprinids, when present, tended to be abundant at both nonburnt and burnt sites. The occurrence of abundant populations of Chub and Ruivaco at sites recently burnt site are suggestive of resistance. The low abundance of trout (one fish) and 
eel at sites that respectively burnt 10 and 18 years previously are suggestive of either resistance or, given that both taxa are migratory and the individuals captured were probably born after the wildfire events (based on the average longevity of these fishes), a degree of recovery. Although the low species diversity and contrasting ecology of fishes in these upland streams imply that trait differences approximate to taxonomic classification (i.e. differences between respective traits corresponded to the identities of respective taxa, cf. Eros et al., 2009), the functional orientation of trait descriptions provide an useful mechanistic perspective on the ecological phenomena of disturbance, resistance and resilience (Verkaik et al., 2013).

The descriptive trends (summarized by statistical ordination) and specific responses (of the BAI surveys) accord with the expectation that resource specialists are more sensitive to wildfire impacts than resource generalists (Dunham et al., 2003). As invertivorous, coldwater stenotherms that spawn in autumn/winter when post-fire erosive episodes are at their peak, European salmonids are characterized by fire-sensitive traits (cf. North American salmonids; Propst et al., 1992; Rieman and Clayton, 1997; Cooper et al. 2015). However, their comparatively high mobility typically facilitates both impact avoidance and subsequent recolonization (Gresswell, 1999), so they are generally considered to be resilient to wildfire (Rieman and Clayton, 1997; Burton, 2005; Dunham et al., 2007; Sestrich et al., 2011). Although, the trout of these Portuguese streams are potamodromous, their continued absence two years after fire in the BAI survey and, more generally, the lack of a time-related pattern (assumed to represent temporal recovery) in the chronosequence survey suggests their resilience was inhibited in these systems. As fire typically passes over the steep-sided, narrow channels of upland Portuguese streams, leaving riparian vegetation intact (unpublished data), impacted streams were unlikely to have suffered from chronic increased temperatures that can be associated with post-fire increases in solar radiation (Dunham et al., 2007; Sestrich et al., 2011; Cooper et al. 2015). Considering the typically rapid recovery of benthic macroinvertebrate densities (Minshall, 2003; also observed in these streams, unpublished data) the continued absence of trout suggests difficulties in recolonization rather than non-viable post-fire habitats. Potential barriers to migration were evident for several of the fire-impacted fishless sites. According to military maps, three sites (impacted 2, 2, and 15 years previously) had disused water mills less than $3 \mathrm{~km}$ downstream of the survey sites; one site (impacted ten years previously) was immediately upstream of a $1 \mathrm{~m}$ high, stepped culvert (pers. obs. KAM). Despite their small-scale, such structures can fragment river ecosystems and impede dispersal, leaving fish populations vulnerable to subsequent disturbance (Blanchet et al., 2010). While the analysis of fish presence verses barriers was not statistically significant, this result may, in part, be explained by the absence of fish at several burnt sites without barriers where naturally steep channel slopes may have otherwise restricted colonization. However, in this context it is also relevant to note that barriers (in the form of disused mills and their associated lowhead dams) were also present on two sites (impacted 10 and 18 years previously) that appeared to demonstrate partial recovery (trout and eel, respectively).
The traits of fractional spawning, habitat generalism and an omnivorous diet appear to have facilitated the resistance of the cyprinid taxa inhabiting these comparatively isolated hill-streams. Despite the marked differences in biogeography and alien species between Portugal and N. America, this finding alleviates (in part) a concern expressed by Dunham et al., (2003), that fire might be particularly damaging to native fish and therefore facilitate non-native invasions. While quantitative data on non-native species is lacking, no exotic species were captured in this study. Thus it is evident that even in the face of extreme wildfire events, these small upland Portuguese streams remain a viable habitat for endemic Cyprinids (although perhaps less so for native Salmonids).

As catchment erosion and scouring floods are widely recognized as a major fire-related disturbance process (Minshall, 2003; Shakesby 2011), it was not surprising that habitat structure was identified as a key correlate of fish communities in burnt streams. Hill-slope erosion and subsequent in-stream scour tend to increase with increasing stream slope with deleterious consequences for aquatic organisms (Cover et al., 2008; Sestrich et al., 2011). It is, however, notable that the apparent ecological impact was significantly related to the degree of management intervention, increasing with the incidence of bank management and associated channelization. Again, the likely mechanistic process, increased erosive power, has been well-documented in geomorphological studies (Barker et al., 2009) and corroborates with evidence from previous ecological studies (Oscoz et al., 2005; Wyzga et al., 2009). By exacerbating ecological disturbance and impeding recovery, the combined stress of habitat modification and wildfire can provoke a synergistic disturbance interaction.

Wildfire presents a major challenge to the conservation management of riverine fishes. The details of wildfire impact (location, timing, severity, etc.) can only be known retrospectively and can only be anticipated in vague, probabilistic terms. In consequence, scientists must provide ecological information that enables inference over broad spatio-temporal scales (Dunham et al., 2003; Verkaik et al., 2013). Grounded in principles of ecological function, trait-based approaches offer a versatile alternative to the biogeographically limited taxonomic-based analyses. Knowledge of river habitats provides a key auxiliary to the interpretation of trait data, representing the environmental context for both the manifestation of fire-related disturbance processes and the ecological responses of river fishes. Human modification to river habitats, such as channelization and channel damming, can increase the severity of fire-related disturbance and impede ecological recovery, suggesting that the rehabilitation of these habitats could enhance ecological resistance and resilience.

Acknowledgements. The study was funded by the Fundação para a Ciência e Tecnologia (FCT; PTDC/AMB/76006/2006). Thanks are due, for the financial support to CESAM (UID/AMB/50017/2013), to FCT/MEC through national funds, and the co-funding by the FEDER, within the PT202 Partnership Agreement and Compete 2020 (POCI01-0145-FEDER-007638). KAM is recipient of FCT studentship SFRH/BPD98533/2013.The manuscript has been greatly improved by the constructive comments of two anonymous reviewers. 


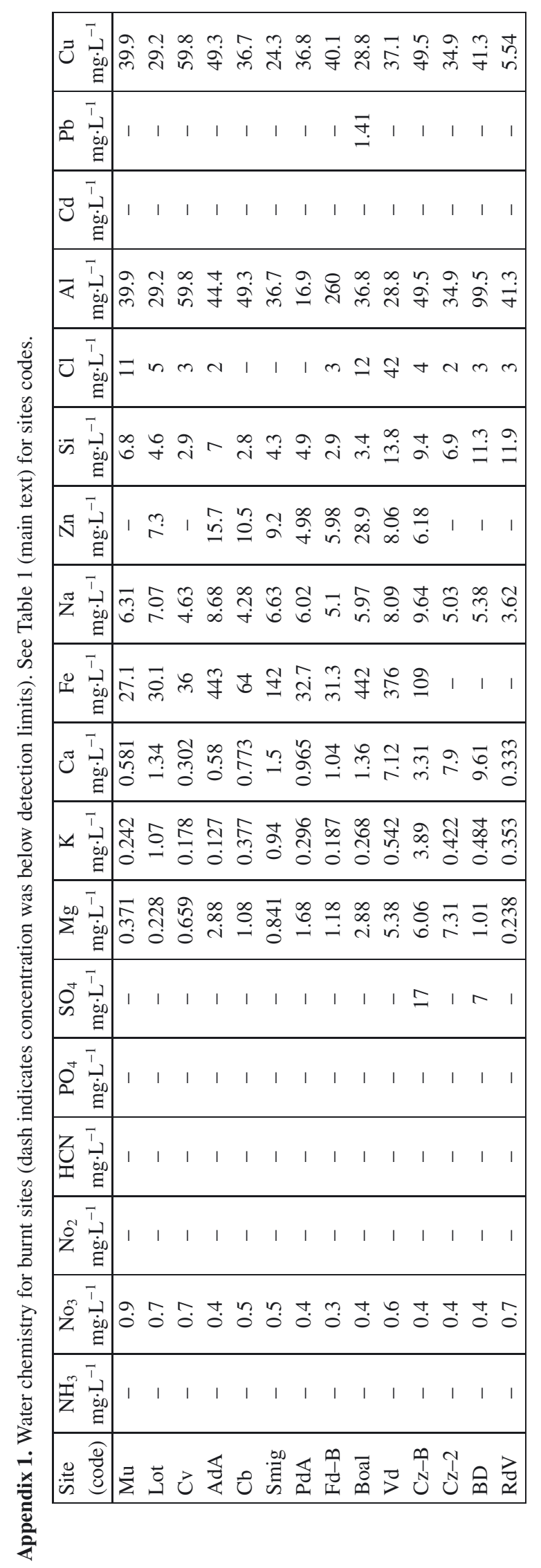

\section{References}

Alvarez-Cabria M., Barquin J. and Juanes J.A., 2011. Macroinvertebrate community dynamics in a temperate European Atlantic river. Do they conform to general ecological theory? Hydrobiologia, 658, 277-291.

Amorim J.H., Keizer J.J., Miranda A.I., and Monaghan K.A., (eds.), 2011. Forest fires research: beyond burnt area statistics. Universidade de Aveiro, Aveiro. 978-972-789-345-4

Arnan X., Rodrigo A., and Retana J., 2006. Post-fire recovery of Mediterranean ground ant communities follows vegetation and dryness gradients. J. Biog., 33, 1246-1258.

Barker D.M., Lawler D.W., Knight K.W., Morris D.G., Davies H.N. and E.J. Stewart, 2009. Longitudinal distributions of river flood power: the combined automated flood, elevation and stream power (CAFES) methodology. Earth Surf. Process. Landforms, 34, 280-290.

Batllori E., Parisien M., Krawchuk M.A., and Moritz M.A., 2013. Climate change-induced shifts in fire for Mediterranean ecosystems. Global Ecology and Biogeography, 22, 1118-1129.

Benda L., Miller D., Bigelow P., and Andras K., 2003. Effects of postwildfre erosion on channel environments, Boise River, Idaho. For. Ecol. Manage., 178, 105-119.

Blanchet S., Olivier R., Etienne R., Lek S. and Loot G., 2010. Species-specific responses to landscape fragmentation: implications for management strategies. Evol. Appl., 3, 291-304.

Bond W.J., and Keeley J.E., 2005. Fire as a global 'herbivore': the ecology and evolution of flammable ecosystems. Trends Ecol. Evol., 20, 387-394.

Bowman D., Balch J.K., Artaxo P., Bond W.J., Carlson J.M., Cochrane M.A., D'Antonio C.M., DeFries R.S., Doyle J.C., Harrison S.P., Johnston F.H., Keeley J.E., Krawchuk M.A., Kull C.A., Marston J.B., Moritz M.A, Prentice I.C., Roos C.I., Scott A.C., Swetnam T.W., van der Werf G.R. and Pyne S.J., 2009. Fire Earth Syst. Sci., 324, 481-484.

Brookes A., 1988. Channelized rivers: perspectives for environmental management. John Wiley, Chichester.

Burton T.A., 2005. Fish and stream habitat risks from uncharacteristic wildfire: Observations from 17 years of fire-related disturbances on the Boise National Forest, Idaho. For. Ecol. Manage., 211, 140-149.

Chaves M.L., Chainho P.M., Costa J.L., Prat N. and Costa M.J., 2005. Regional and local environmental factors structuring undisturbed benthic macroinvertebrate communities in the Mondego River basin, Portugal. Archiv Fur Hydrobiologie, 163, 497-523.

Clavero M. and Garcia-Berthou E., 2006. Homogenization dynamics and introduction routes of invasive freshwater fish in the Iberian Peninsula. Ecol. Appl., 16, 2313-2324.

Cooper S.D., Page H.M., Wiseman S.W., Klose K., Bennett D., Even T., Sadro S., Nelson C.E., Dudley T.L. 2015. Physicochemical and biological responses of streams to wildfire severity in riparian zones. Fresh. Biol., 60, 2600-2619.

Cover M.R., May C.L., Dietrich W.E. and Resh V.H., 2008. Quantitative linkages among sediment supply, streambed fine sediment, and benthic macroinvertebrates in northern California streams. J. N. Am. Benthol. Soc., 27, 135-149.

Dunham J.B., Young M.K., Gresswell R.E. and Rieman B.E., 2003. Effects of fire on fish populations: landscape perspectives on persistence of native fishes and nonnative fish invasions. For. Ecol. Manage., 178, 183-196.

Dunham J.B., Rosenberger A.E., Luce C.H. and Rieman B.E., 2007. Influences of wildfire and channel reorganization on spatial and temporal variation in stream temperature and the distribution of fish and amphibians. Ecosystems, 10, 335-346. 
Environment Agency, 2003. River habitat survey in Britain and Ireland; field survey guidance manual (version 2003, Bristol).

Eros T., Heino J., Schmera D. and Rask M., 2009. Characterising functional trait diversity and trait-environment relationships in fish assemblages of boreal lakes. Fresh. Biol., 54, 1788-1803.

FAME, 2005. Manual for the application of the European Fish Index - EFI. A fish-based method to assess the ecological status of European rivers in support of the Water Framework Directive. Version 1.1.

Filipe A.F., Marques T.A., Seabra S., Tiago P., Ribeiro F., Da Costa L.M., Cowx I.G. and Collares-Pereira M.J., 2004. Selection of priority areas for fish conservation in Guadiana River basin, Iberian Peninsula. Conserv. Biol., 18, 189-200.

Gresswell R.E., 1999. Fire and aquatic ecosystems in forested biomes of North America. Trans. Amer. Fish. Soc., 128, 193-221.

IPCC WG II, 2014. Climate change 2014: impacts, adaptation and vulnerability, Volume II: Regional Aspects. 23. Europe. IPCC, Geneva.

Johnstone J.F., Rupp T.S., Olson M. and Verbyla D., 2011. Modeling impacts of fire severity on successional trajectories and future fire behavior in Alaskan boreal forest. Landscape Ecol., 26, 487-500

Kiss L., Magnin F., 2006. High resilience of Mediterranean land snail communities to wildfires. Biodiversity and Conservation, 15, 2925-2944.

Kottelat M. and Freyhof J., 2007. Handbook of European freshwater fishes. Kottelat, Cornol, Switzerland and Freyhof, Berlin, Germany.

Legendre P. and Legendre L., 2012. Numerical Ecology, Third Edition. Elsevier, Amsterdam.

Leunda P.M., Elvira B., Ribeiro F., Miranda R., Oscoz J., Alves M.J. and Collares-Pereira M.J., 2009. International Standardization of Common Names for Iberian Endemic Fresh. Fishes. Limnética, 28, 189-202.

Magalhaes M.F., Batalha D.C. and Collares-Pereira M.J., 2002. Gradients in stream fish assemblages across a Mediterranean landscape: contributions of environmental factors and spatial structure. Fresh. Biol., 47, 1015-1031.

Magalhaes M.F., Beja P., Schlosser I.J. and Collares-Pereira M.J., 2007. Effects of multi-year droughts on fish assemblages of seasonally drying Mediterranean streams. Fresh. Biol., 52, 1494 1510.

Mellon C.D., Wipfli M.S. and Li J.L., 2008. Effects of forest fire on headwater stream macroinvertebrate communities in eastern Washington, USA. Fresh. Biol., 53, 2331-2343.

Minshall G.W., 2003. Responses of stream benthic macroinvertebrates to fire. For. Ecol. Manage., 178, 155-161.

Minshall G.W., Brock J.T. and Varley J.D., 1989 Wildfires and Yellowstone's stream ecosystems. BioScience, 39, 707-715.

Minshall G.W., Robinson C.T. and Lawrence D.E., 1997. Immediate and mid-term responses of lotic ecosystems in Yellowstone Natural Park, USA to wildfre. Can. J. Fish. Aqua. Sci., 54, 2509_ 2525.

Monaghan K.A. and Soares A., 2010. The bioassessment of fish and macroinvertebrates in a Mediterranean-Atlantic climate: Habitat assessment and concordance between contrasting ecological samples. Ecol. Ind., 10, 184-191.

Monaghan K.A., Fonseca M.M., Domingues I. and Soares A., 2008. The effects of small-scale impoundments and bank reinforcing on fish habitat and composition in semi-natural streams. Polish J. Ecol., 56, 647-657.

Moreira F., Rego F.C. and Ferreira P.G., 2001. Temporal (19581995) pattern of change in a cultural landscape of northwestern Portugal: implications for fire occurrence. Landscape Ecol., 16, $557-567$.
Oscoz J., Leunda P.M., Miranda R., Garcia-Fresca C., Campos F. and Escala M.C., 2005. River channelization effects on fish population structure in the Larraun river (Northern Spain). Hydrobiologia, 543, 191-198.

Pausas J.G., 2004. Changes in fire and climate in the eastern Iberian Peninsula (Mediterranean basin). Clim. Change, 63, 337-350.

Pausas J.G. and Keeley J.E., 2009. A Burning Story: The Role of Fire in the History of Life. Bioscience, 59, 593-601.

Pausas J.G., Blade C., Valdecantos A., Seva J.P., Fuentes D., Alloza J.A., Vilagrosa A., Bautista S., Cortina J. and Vallejo R., 2004a. Pines and oaks in the restoration of Mediterranean landscapes of Spain: New perspectives for an old practice - a review. Plant Ecol., 171, 209-220.

Pausas J.G., Bradstock R.A., Keith D.A., Keeley J.E. and Network G.F., 2004b. Plant functional traits in relation to fire in crown-fire ecosystems. Ecology, 85, 1085-1100.

Pausas J.C., Llovet J., Rodrigo A. and Vallejo R., 2008. Are wildfires a disaster in the Mediterranean basin? - A review. Int. J. Wildland Fire, 17, 713-723.

Pires D.F., Pires A.M., Collares-Pereira M.J. and Magalhaes M.F., 2010. Variation in fish assemblages across dry-season pools in a Mediterranean stream: effects of pool morphology, physicochemical factors and spatial context. Ecol. Fresh. Fish, 19, 74-86.

Propst D.L., Stefferud J.A. and Turner P.R., 1992. Conservation and status of Gila trout, Oncorhynchus gilae. Southwestern Naturalist, 37, 117-125.

Ramchunder S.J., Brown L.E. and Holden J., 2013. Rotational vegetation burning effects on peatland stream ecosystems. J. Appl. Ecol., 50, 636-648.

Reeves G.H., Bisson P.A., Rieman B.E. and Benda L.E., 2006. Postfire logging in riparian areas. Conserv. Biol., 20, 994-1004.

Ribeiro F., Cowx I.G. and Collares-Pereira M.J., 2000. Life history traits of the endangered Iberian cyprinid Anaecypris hispanica and their implications for conservation. Archiv Fur Hydrobiologie, 149, 569-586.

Ribeiro F., Beldade R., Dix M. and Bochechas J., 2007. Carta Piscícola Nacional Direcção Geral dos Recursos FlorestaisFluviatilis, Lda.

Ribeiro F., Collares-Pereira M.J. and Moyle P.B., 2009. Non-native fish in the fresh waters of Portugal, Azores and Madeira Islands: a growing threat to aquatic biodiversity. Fish. Manag. Ecol., 16, 255-264.

Rieman B. and Clayton J., 1997. Wildlife and native fish: Issues of forest health and conservation of sensitive species. Fisheries, 22, 6-15.

Rinne J.N., 1996. Short-term effects of wildfire on fishes and aquatic macroinvertebrates in the Southwest United States. North Am. J. Fish. Manage., 16, 653-658.

Sanjur O.I., J.A. Carmona and I. Doadrio, 2003. Evolutionary and biogeographical patterns within Iberian populations of the genus Squalius inferred from molecular data. Mol. Phylogenet. Evol., 29, 20-30.

Santos J.M., Ferreira M.T., Pinheiro A.N. and Bochechas J.H., 2006. Effects of small hydropower plants on fish assemblages in medium-sized streams in central and northern Portugal. Aquat. Conserv. Mar. Freshhw. Ecosyst., 16, 373-388.

Sestrich C.M., McMahon T.E. and Young M.K., 2011. Influence of Fire on Native and Nonnative Salmonid Populations and Habitat in a Western Montana Basin. Trans. Amer. Fish. Soc., 140, 136146.

Shakesby R.A. 2011. Post-wildfire soil erosion in the Mediterranean: review and future research directions. Earth-Sci. Rev., 105, 71100. 
Spencer C.N. and Hauer F.R., 1991. Phosphorus and nitrogen dynamics in streams during wildfire. J. N. Am. Benthol. Soc., 10, 24-30. Spencer C.N., Gabel K.O. and Hauer F.R., 2003. Wildfire effects on stream food webs and nutrient dynamics in Glacier National Park, USA. For. Ecol. Manage., 178, 141-153

Syphard A.D., Radeloff V.C., Keeley J.E., Hawbaker T.J., Clayton M.K., Stewart S.I. and Hammer R.B., 2007. Human influence on California fire regimes. Ecol. Appl., 17, 1388-1402.

Vaz P.G., Warren D.R., Pinto P., Merten E.C., Robinson C.T. and Rego F.C. 2011. Tree type and forest management effects on the structure of stream wood following wildfires. For. Ecol. Manage., 262, 561-570.

Vaz P.G., Dias S., Pinto P., Merten E.C., Robinson C.T., Warren D.R. and Rego F.C., 2014. Effect of burn status and conditioning on colonization of wood by stream macroinvertebrates. Freshw. Sci., $33,832-846$.
Verkaik I., Rieradevall M., Cooper S.D., Mekack J.M., Dudley T.L. and Prat N. 2013. Fires as a disturbance in mediterranean climate streams. Hydrobiologia, 719, 353-382.

Webb C.T., Hoeting J.A., Ames G.M., Pyne M.I. and Poff N.L., 2010. A structured and dynamic framework to advance traits-based theory and prediction in ecology. Ecol. Lett., 13, 267-283.

Wyatt R.J., Barnard S. and Lacey R.F., 1995. Use of HABSSCORE $\mathrm{V}$ software and application to impact assessment. R and D Note 400. National Rivers Authority, Bristol.

Wyzga B., Amirowicz A., Radecki-Pawlik A. and Zawiejska J., 2009. Hydromorphological conditions, potential fish habitats and the fish community in a mountain river subject to variable human impacts, the Czarny Dunajec, Polish Carpathians. River Res. Appl., 25, 517-536.

Cite this article as: K.A. Monaghan, A.L. Machado, F.J. Wrona, A.M.V.M. Soares, 2016. The impact of wildfire on stream fishes in an Atlantic-Mediterranean climate: evidence from an 18-year chronosequence. Knowl. Manag. Aquat. Ecosyst., 417, 28. 